\title{
Transatlantic Relations Under US President Joe Biden
}

\author{
Jackson Janes
}

Received: 17 December 2020 / Accepted: 21 January 2021 / Published online: 29 March 2021

(C) Springer Fachmedien Wiesbaden GmbH, ein Teil von Springer Nature 2021

\begin{abstract}
This essay examines three levels of challenges the new U.S. President Joe Biden must confront: those in the global arena, those that are pertinent for transatlantic relations and those which relate specifically to German-American relations. Plotting steps in all three arenas will require coordination with partners and engagement with competitors. That triangle requires understanding how the three levels overlap, where they can complement each other and where they will require finding common ground.
\end{abstract}

Keywords U.S. Presidency · Joe Biden · Global challenges · Transatlantic relations · German-American Relations

\section{Die transatlantischen Beziehungen unter US-Präsident Joe Biden}

Zusammenfassung Dieser Essay untersucht drei Ebenen an Herausforderungen, denen sich der neue US-Präsident Joe Biden gegenübersieht: solche auf globaler Ebene, die transatlantischen Beziehungen sowie die deutsch-amerikanischen Beziehungen im Speziellen. All diese Bereiche erfordern es, sich mit Partnern abzustimmen und mit Wettbewerbern auseinanderzusetzen. Die verschiedenen Ebenen erfordern ein Verständnis dafür, wie sie sich überschneiden, wo sie sich gegenseitig ergänzen können und wo es Gemeinsamkeiten zu finden gilt.

Schlüsselwörter U.S. Präsidentschaft · Joe Biden · Globale Herausforderungen · Transatlantische Beziehungen · Deutsch-amerikanische Beziehungen

Dr. J. Janes $(\bowtie)$

American Institute for Contemporary German Studies (AICGS), Senior Fellow - German Marshall Fund of the United States, 1700 18th street NW, Washington DC, 20009, USA

E-Mail: jjanes@gmfus.org 


\section{Introduction}

Alexis de Tocqueville is often a source of wisdom for US-Americans seeking to understand themselves. His famous work "Democracy in America" appeared in 1835 and continues to provide insight about the unique character of the United States. In a particularly relevant point for the year 2020, he wrote the following about US-American elections:

As the election draws near, intrigues grow more active, agitation is more lively and wider spread. The citizens divide up into several camps, each of which takes its name from its candidate. The whole nation gets into a feverish state; the election is the daily theme of comment in the newspapers and private conversations, the object of every action and the subject of all thought, the sole interest of the moment. (Tocqueville 1835)

Regarding the presidency at this point in the campaign, Tocqueville states:

The president, for his part, is consumed by the need to defend his record. He no longer governs in the interest of the state but rather in the interest of his reelection. He prostrates himself before the majority, and often, rather than resist its passions as his duty requires, he courts favor by catering to its whims. (Tocqueville 1835)

More than 180 years later Tocqueville would probably not have been surprised to see what has just unfolded in 2020 or for that matter the elections of the last few decades.

The battle between Joe Biden and President Donald Trump might be seen as an enormous catalyst for U.S. democracy at work. Measured by the participation in this election, more Americans voted in this election than at any time in the history of the country, projected to be over 160 mil. Given that around 239.2 mil. Americans were eligible to vote in 2020 , the projected number of voters equals a $66.8 \%$ turnout rate with Biden getting 81.8 mil. votes to President Trump's 74.9 mil.

Of course the election was determined by the electoral college process, meaning that the winning candidate had to record 270 or more electoral votes. Following a nail-biting vote count well after November 3, 2020, Joe Biden was awarded enough votes to be called President-elect along with his running partner, Kamala Harris as Vice President-elect. The complicated system of the electoral college has been at the heart of the post-election period which has generated enormous conflict within the country with accusations of fraud being made by Trump who has refused to recognize Biden's victory. The unprecedented effort of the Trump team and Republican supporters to raise doubt about the final results of the vote in several states has delayed the transition process from unfolding in the run up to the inauguration on January 20, 2021.

Inheriting a polarized country is not new for any president including Joe Biden. Presidential elections have been close calls in many instances in the recent past. The election of 2000 was decided in effect by the Supreme Court when it stopped the vote count in Florida on legal grounds leaving a country divided about the winner of the election. Al Gore could have challenged the court's decision but he decided 
to concede sparing the country from a continuing drama. One can go back to the Kennedy-Nixon election which was a very narrow victory for John F. Kennedy and could have been challenged by Richard Nixon but he conceded rather than fight.

Yet the election of 2020 will be remembered for a drama and the poisonous atmosphere largely created by Trump who cast the election as rigged and "stolen" from him and threatened to run against Biden in 2024. The millions of Americans who follow Trump and his social media feed may continue to believe that Biden is an illegitimate president after he is inaugurated, yet many Americans felt that same way when Trump was elected in 2016 and indeed when George W. Bush was confirmed in 2000.

How Biden will confront this national divide in the coming years will be one of his most serious challenges. The capacity to deal with the sources of this division will not be accomplished in four years as the evolution of it reaches back many decades and involves a thorough and sober look at its economic, social, and cultural roots. It is for that reason that President Biden will have to be squarely focused on the domestic policy demands he confronts starting with the COVID-19 pandemic and its economic repercussions. The foreign policy dimensions of his administrations will be equally demanding but his success in that arena will also depend on securing support for them at home. That begins with the effort to find common ground with the Senate. With only the vote of Vice President Harris as the deciding factor in the Senate and the House of Representatives with a thin Democratic majority, the prospects for legislation will be complicated. Neither of those bodies will be easy partners. But each will contain members listening to their respective constituents and their concerns. In most cases, foreign policy issues will be less of a priority for many of them. While the president has a wide margin for foreign policy decision making, there is still a requirement for Senate confirmation for treaties and Congressional approval for military actions as well as for budgets.

Biden has decades of experience in foreign affairs as does his proposed administration leadership in that area of policy. He has emphasized that he is not following the slogan of Trump's Make America Great Again and will see to reengage with allies and global organizations in which he can bring America back as a partner and indeed a leader. That will involve confirming current commitments and engagements such as in NATO as well as rejoining international agreements and institutions such as the Paris Accord on Climate or the World Health Organization. He may reverse decisions made by the Trump administration with regards to the military deployments around the world, and reopen negotiations to join trade agreements. The ability to restore some of these connections will be at his discretion but there will be others where he will need Congress to support his proposed policies.

This essay will examine three levels of challenges Biden must confront: those in the global arena, those that are pertinent for transatlantic relations and those which relate specifically to German-American relations. Plotting steps in all three arenas will require coordination with partners and engagement with competitors. That triangle requires understanding how the three levels overlap, where they can complement each other and where they will require finding common ground. 


\section{Global challenges}

The United States is not the same country it was in 2016. The same applies to Europe. And the world at large is in serious transformation. The events over the past four years have generated new challenges and that will require new thinking about how to meet them.

The Coronavirus pandemic has only been impacting the global community for a year and yet it has changed the coordinates of our efforts to deal with threats we cannot see. COVID-19 has wreaked havoc on the health and the economies of countries around the world and underscored the problems we face in a globalized network of interdependent nations struggling to respond. The urgency of dealing with the threat that knows no borders has underscored the need for international cooperation. It has also generated fear which can be toxic to aspirations for cooperation both within nations and across borders.

There has also been a changing equation of military power and influence on the world stage, creating a need to rethink the challenge of sustaining a peaceful world which is threatened by great power competition for power and influence. The primary arenas for the United States in that competition will be a facing off with China and Russia. Yet that competition will involve and impact other hot spots around the world.

The danger of climate change is increasingly visible in many parts of the world including the United States leaving ever diminishing time to effectively respond. The Trump administration has refused to enter into a global effort in response, having exited from the Paris accords and promoting skepticism about climate change at home. Biden has emphasized that he will reenter the Paris accords and has nominated former Secretary of State John Kerry to be his envoy on the issue. Yet connecting climate change with a complex web of domestic politics remains a challenge to get beyond rhetoric and achieve real global impact.

The fundamentals of our economic system are being challenged at the state and local levels as the forces of digitalization and technological change are both destroying and reshaping the infrastructure of our societies leaving gaps and fissures, which are threats to the political and social stability of countries across the world. The populist waves in various democracies are testimony to the backlash against these asymmetries and are not likely to retreat in the near future.

One of the central tectonic changes in the coming years is the emerging rivalry between the United States and China which will dominate the global agenda in the foreseeable future. But in the longer run the United States and its partners confront the global transformations marked as much by a clash of great powers as by threats which are interconnected with all of us: financial crises, nuclear proliferation, migration trends, global production chains between nation states, and the impact of artificial intelligence and digital revolutions which will change the basis of our societies. How we deal with these changes and challenges is not a question of whether we are all threatened. The issue is how we respond.

The Biden administration maintains that it is bringing back the United States from an America First policy to a position of leadership on the world stage. After four years of Trump that might sound appealing to Americans and some Europeans 
but will not be greeted with enthusiasm in Beijing or Moscow among other places. But either way it will not be an easy undertaking.

Biden presented his strategy and thinking early in 2020 in an essay in Foreign Affairs. He stated his intention:

As president, I will take immediate steps to renew U.S. democracy and alliances, protect the United States' economic future, and once more have America lead the world. [...] The Biden foreign policy agenda will place the United States back at the head of the table, in a position to work with its allies and partners to mobilize collective action on global threats. The world does not organize itself. (Biden 2020)

After his election in November 2020, Biden as President-elect began to assemble one of the most experienced national security and foreign policy teams in decades. They grasp that the world has changed and that they cannot hit the rewind button to 2016. Most important, they understand that the primary challenge they confront is fixing America - the key to the success or failure of Biden's presidency. But the role of foreign policy in helping the United States to recover its strength, capacities and indeed confidence at home and abroad is of central importance to restoring American confidence and engagement in an unpredictable world. That is a case Biden has to make to a weary America, particularly its middle class.

The success of his foreign policy agenda will depend on establishing his priorities and engaging with partners at eye level while sorting out what can be negotiated with competitors. The table Biden envisions may not accommodate a singular head but rather a larger round table of stake holders engaged in a common agenda. Some argue that the composition of power and influence in the global arena may be entering a phase, described by Charles Kupchan as "No One's world": "The twenty first century will not be America's, China's Asia's or anyone else's - it will belong to no one. The emergent international system will be populated by numerous power centers as well as multiple versions of modernity. An interdependent world will be without a single center of gravity or global guardian" (Kupchan 2012, p. 3). Biden is likely not convinced of that thesis and will argue the he intends to restore the primacy of U.S. global power and influence. But there can be no doubt that the global environment of the third decade will not look like the bipolar world in which Biden was immersed during his long political career as well as the more diffused era which followed it. What it will ultimately look like remains to be seen.

While the United States has been preoccupied with its domestic quarrels over recent years, other countries have not been standing still. In the Asia-Pacific region we have seen the emergence of a new trade agreement, the Regional Comprehensive Economic Partnership which includes China but excludes the United States. In Europe, allies are debating the idea of a greater emphasis on strategic autonomy from the United States, in light of their perception of more unpredictability and uncertainty in Washington. Given its economic and military powers, the United states remains a globally dominant force but Washington now sees a transformation in its allies in which there is more of an allergy against being perceived as an object of American foreign policy rather than a subject. 
As part of his effort to reclaim America's primary role on the world stage, Biden has proposed to host a 'Summit for Democracy' involving partners around the world and issuing challenges to authoritarian leaders. Dealing with autocratic states and their governments remains a necessity and will require a balanced approach but emphasizing the common commitments to democracy and the rule of law while pursing pragmatic policies is unavoidable. Focused negotiations with for example China, Russia, Turkey, Saudi Arabia, Syria and Iran remain requirements if also shoring up alliances with like-minded partners who believe that liberal internationalism is a better strategy than state-controlled policies.

The Biden presidency will need to be specific in its policy priorities and choices that will have repercussions for allies and partners. The list will be a long one. That involves deciding on how to leverage pressure on Iran and Gulf Arab states to achieve an agreement to replace the Iran nuclear deal. It will also require forging common ground trade agreements involving cyber security, data sharing and technology developments. Getting agreements on arms control with Russia will be of importance with the hope of engaging China in such negotiations. China will be a dominant theme in the Biden administration agenda across several areas.

A focus on the global challenges will also involve policies directed at regions of importance beyond Europe and Asia. The increasing role of India on the world stage will be of paramount importance in dealing with an array of issues involving climate policies and trade networks. The volatile situation in the Middle East continues to generate uncertainty. Biden will inherit efforts made by the Trump administration to isolate Iran and to support the expansion of relations between Arab states and Israel. He will also inherit a complex situation involving the ongoing conflicts in Syria, which will be a similarly complicated multi-country exercise including Russia, as will any effort to reset negotiations between Israelis and Palestinians.

There is also the uncertain path forward in Afghanistan and Iraq in which other allied countries, particularly Germany, have a stake. And then there is North Korea's continued development of nuclear weapons capacities despite love letters exchanged between Trump and the North Korean leader. The Biden administration will be faced with the challenges in the Western Hemisphere, in which many nations are suffering from the pandemic, continued violence, narco trafficking and populist dictators. The renegotiation of trade deals with Mexico and Canada have not confronted let alone solved all of those challenges.

Finally, there will be a need to direct attention toward African leaders and their needs amidst increasing competition with Chinese efforts as securing a foot hold on that continent (Saldinger 2020).

While the Biden administration is attempting to explain to Americans that his domestic policies are designed to help renew and strengthen the United States, he is also faced with explaining why engagement in all these global arenas remains of strategic interest to the United States. In order to make that case, Biden is going to need friends and allies to help shoulder those burdens. His best option is to pursue a more effective transatlantic bargain with the EU, strengthen NATO and engage his allies with the global challenges ahead. 


\section{Transatlantic relations}

The reaction in almost all of Europe following the U.S. presidential election was a mix of relief as well as uncertain expectations. The fact that Trump was so disliked in the majority of European countries had as much to do with his personal style as well as his policies and the way he implemented them. Biden was seen as the anti-Trump but that alone did not address the expectations issues connected with his upcoming presidency. There was a shared mantra throughout Europe that essentially said: after Trump, there will be no easy return to the way we were with Barack Obama. Yet that mantra in itself begs the question of what actually was the way transatlantic relations were prior to Trump. They were not always running on a smooth road but rather were already in the process of transitioning under Obama, Bush Jr. and Bill Clinton. In fact, they had been in a phase of serious transformation over the past three decades.

Thirty years after the end of the Cold War, transatlantic relations are entering another era, yet without a name and without much consensus about what to expect. The post-Cold War era began with a great deal of hubris on both sides of the Atlantic but today it may be called the post-post-Cold War era. What shall we call it? The era of illusions, an age of anxiety, a return to realism?

Whatever is in store for us, we should recall the words of former Secretary of Defense Donald Rumsfeld who reminded us that there are things we know, we don't know as well as those we don't know we don't know. Not many could have foreseen a pandemic which would circle the globe in 2020 and leave hundreds of thousands dead in its wake. Both Brexit and the election of Trump were shocks to assumptions about sustainability of the European Union and the transatlantic alliance. But the attacks on 9/11 were also unexpected wake up calls, as was the explosion of ISIS in Iraq following the disastrous outcome of the U.S. led invasion in 2003. The lingering depths of the 2008 Great Recession or the great migrations of people looking for refuge around the globe from either violence or climate change remain unmet challenges. All of these demands have left the ability to find a consensus on effective responses urgent but complicated. In this environment, transatlantic relations are facing both risks and opportunities alike. The election of Biden offers both.

The opportunities for transatlantic relations are to be found in the shared challenges we face as well as in the political will to meet them on both sides of the pond. The combined resources of these relations were described in the recent report issued by the European Union on transatlantic relations.

Today, our combined global power and influence remains unrivaled. We are home to nearly a billion people and are the two largest blocs of advanced democracies. We account for about a third of the world's GDP and trade, and $60 \%$ of foreign direct investment. The density and openness of transatlantic trade and investment creates millions of jobs and shapes large parts of the global economy. We have the reach to set regulations and standards that are replicated 
across the world. We are the primary drivers of innovation and the world's research powerhouses, developing technology from 5G to vaccines. (European Commission 2020)

In addition to the economic and political structures binding the transatlantic community, NATO remains the backbone of security for the alliance, which is also unrivaled in terms of its capacities and sustained strength of commitment. Yet adapting to a new era of challenges comes with risks. As the Reflection Group pointed out in its report to the NATO General Secretary.

NATO stands as history's most successful alliance, encompassing nearly a billion people and half of global GDP across a space that stretches from the Pacific coast of North America to the Black Sea. Yet, future uncertainties demand that NATO continues to adapt. The world of the next ten years will be very different than the world that the Alliance inhabited either during the Cold War or the decades that immediately followed. It will be a world of competing great powers, in which assertive authoritarian states with revisionist foreign policy agendas seek to expand their power and influence, and in which NATO Allies will once again face a systemic challenge cutting across the domains of security and economics. Well-known threats like terrorism, in all its forms and manifestations will persist, even as new risks loom from pandemics and climate change, and as emerging and disruptive technologies (EDTs) present both dangers and opportunities for the Alliance. (NATO 2020)

Amidst these dangers are also domestic centrifugal forces, pulling at the fabric of Europe and the United States fanned by economic asymmetries and political grievances which led to Brexit, populist surges in several countries in Europe and the election of Trump to the American presidency. These developments have generated threats to what has been called The West: that combination of political economic and social organization which championed the so-called liberal international order. But that picture has been challenged by other versions emerging elsewhere around the globe which question many assumptions made after the fall of the Berlin Wall including the ultimate efficiency of liberal democracy, the necessity of an open and global market for capitalism, and the increasing need for international governance policy and institutions. Today, those challenges are embodied in the rise of China which rejects many of those assumptions and offers its own economic success as evidence of alternatives. Even in Europe there are voices which argue that other forms of democracy are more viable, including illiberal democracy as espoused by the leadership in Hungary.

Transatlantic challenges are occurring simultaneously on both sides of the relationship. Europe is facing its own versions in debates over how it envisions its future. Some argue that the recent experience with Trump requires rethinking the dependence on the United States for its defense in the name of more "strategic autonomy" (see Hans-Jochen Luhmann's contribution in this issue). Others argue that there is no substitute for the defense shield which the U.S. still holds over Europe even though Europe can do far more to upgrade its capabilities. Other debates center around the role of data protection and cyber security with some arguing that the 
dominant presence of American tech firms has to be monitored and controlled by EU regulations and institutions. Then there are arguments about trade surpluses, energy supplies and the particular issue of the Nord Stream 2 gas pipeline as potentially increasing European dependence on Russia. These are all arguments within Europe as well as across the Atlantic.

There is nothing new about transatlantic frictions across a variety of sectors. However, because of the interplay between transatlantic debates and issues and the larger global arena in which they occur, there is need to sustain a layer of trust in the transatlantic dialogue based on shared goals as well as shared values behind them. That interests can and will clash within these debates is not surprising or disturbing as long as the larger framework in which they are discussed is not fundamentally questioned. Yet that is exactly where we may find the weakest link in the chain. The experiences in Europe with the Trump administration's rhetoric and actual policies have generated uncertainty about what expectations can be realistic with regard to the long-term predictability of American foreign policy directions. At the same time, the American debate about what it can expect from the EU is influenced by questions about its capacities, coherence and commitments to take on more responsibilities within the regional context as well as on the global stage, beyond rhetoric and stated intentions.

The Biden administration is starting its tenure with the assumption that there need to be answers to four major questions it poses about the transatlantic relationship. They are: where, when and how do we need each other and most importantly why. The devil lies in the details and there will be disagreements involved in forging the answers, both within Europe and within the United States. Biden's team will quickly want to move beyond merely similar statements with European partners to common action: whether on COVID-19, climate change, economic recovery, the rise of China and resurgence of Russia, or more broadly the contest between authoritarianism and liberal democracy.

While the strategic center of the world is shifting to Asia, the Biden presidency presents an opening for Europe. Joint projects need to be planned with a bipartisan consensus in mind. There have been several recent efforts to describe how that strategy can be pursued.

A recent joint report from the Kennedy School of Government and the German Council on Foreign Relations layer out three major themes to encompass such a consensus.

1. Rebuild the bonds of trust at the heart of our alliance and revitalize our democracies;

2. Commit to a joint strategy to meet global challenges and defend liberalism; and

3. Transform our political, military, technological and economic capacity to be the most effective force for freedom and rules- based order in a challenging world. (DGAP 2020)

All of these challenges involve engagement in more than the transatlantic network. They include a number of specific areas and issues: Economics and Trade, Security and Defense, the role of China and Russia, Energy Policy and Climate Change, 
protecting Democracy, the fast pace of technology and dealing with the instability in the Middle East and Northern Africa.

Another report was issued by the German Marshall Fund of the United States which lays put a similar set of challenges for transatlantic relations.

In the face of existential challenges, such as climate change, pandemics, and competition from China, neither the United States nor its European partners can effectively act alone. Rather, these problems offer us an opportunity to find new ways to work together to build a better future for our people and the world. Our publics support such cooperative effort. Roughly six-in-ten Americans and Europeans believe that when dealing with major international issues their nation should take into account other countries' interests, even if it means making compromises. In so doing, we can set an example for the world, laying the foundation for much broader cooperation among like-minded democracies that ultimately will be necessary to cope with what today are truly global challenges. In the process, we can transform the transatlantic relationship, assert U.S.-European leadership, affirm our citizens' faith in our democratic values and each other, and demonstrate the ability of our democratic institutions to solve their people's problems. (GMF 2020)

In both these reports among many others which have been generated in the past year, the emphasis is not on restoration but transformation of the transatlantic relationship. There is also a shared emphasis on coordinating expectations and capacities to meet these challenges. The Biden administration has emphasized its intention to renew and pursue that coordination but that is not going to happen easily without compromises.

One of the difficulties is synchronizing the decision-making processes on both sides of the Atlantic particularly in light of the changes in Washington D.C. under a new administration as well as similar transformations and complications in Europe.

The EU is a complex decision-making machine. It is made up of multiple actors and influences including the Council of the EU, its Commissioners, and the members of the European Parliament. There is also a constant churning within these bodies impacted by national elections in the twenty-seven member states. Thus, creating the basis of a consensus on policy issues and decisions is a fragile process. As an illustration: four years have passed by, from the Brexit vote in the United Kingdom to the signing of a resolution on how to manage it.

The same thing can be said about American policy decision making as a complex, sometimes contradictory and indeed unpredictable process. The complexity of the relationship between the presidency and the Congress can be confusing when it comes to judging matters dealing with budgets, treaties and declarations. Despite the wide range of authority the president has in the foreign policy arena, the Congress, Senate and the House of Representatives, impact the parameters of legislation, making it a necessary subject of concern for both allies and competitors. With Congressional elections every two years, which can change the composition of Congress and presidential elections every four years, that are increasingly resulting in extremely close races, the questions of continuity and sustainability of American policy commitments become more prevalent. As an example, President Biden will 
likely reverse many decisions made in the Trump administration regarding Iran, trade negotiations or climate policy. Many in Europe question whether those changes will hold under a successor president.

Overcoming these challenges will require answering the four questions raised earlier: how, where, when and why do the United States and Europe understand how they need each other? The answers need to be more than tactical. The focus on defense budgets and capabilities, regulatory policies, trade negotiations, or cooperating in international organizations is essential for implementing policies. Yet the strategic thinking required to make the transatlantic relationship stronger needs to be shared not only at the elite levels but also within the domestic arenas, particularly with regard to the answer to the question: why?

In some areas, such as alliance defense, there must be support for the bargain of mutual reliability. Within NATO, that is embodied in Article Five of the treaty. 70 years after the foundations of NATO were established during the Cold War, the conditions for that alliance are no longer the same. Threats are no longer solely embodied by the number of missiles and tanks, but today by cyber weapons, digital vulnerabilities and political disinformation sowing doubt and confusion. Yet the commitment of mutual defense remains the core of the alliance. How, when and where that commitment is demonstrated and assured can change but not the answer to why as it has to do with values as much as interests concerning what we share in defending.

The recent tensions over defense expenditures in the NATO member countries has underlined the challenge of reaching a consensus. Biden has argued that his administration will not approach the alliance with a transactional view.

The alliance transcends dollars and cents; the United States' commitment is sacred, not transactional. NATO is at the very heart of the United States national security, and it is the bulwark of the liberal democratic ideal - an alliance of values, which makes it far more durable, reliable, and powerful than partnerships built by coercion or cash. As president, I will do more than just restore our historic partnerships; I will lead the effort to reimagine them for the world we face today. (Biden 2020)

Yet the opportunity and the challenge for Europe is to respond in kind. That will require making difficult decisions on both defense spending as well as strategic thinking and engagement and then ultimately selling that to the general public (Gottemoeller 2019).

The same is true of the transatlantic economic relationships. While the interdependence of transatlantic bonds is deep and wide, meshing the interests of the two economic spheres is based on reaching agreements which enhance the prosperity of both sides of the Atlantic. Biden has stated that he intends to make economic security a matter of national security.

A foreign policy for the middle class will also work to make sure the rules of the international economy are not rigged against the United States-because when American businesses compete on a fair playing field, they win. I believe in fair trade. More than 95 percent of the world's population lives beyond our 
borders-we want to tap those markets. We need to be able to build the very best in the United States and sell the very best around the world. That means taking down trade barriers that penalize Americans and resisting a dangerous global slide toward protectionism. (Biden 2020)

The challenge for the transatlantic relationship is to find common ground on these goals as the European partners are also interested in sustaining their economic prosperity. Arguments over tariffs and taxes, regulatory oversight and export surpluses are inevitable in reaching compromises. The tone of a Biden administration in negotiations will not continue to attack Europe as a foe but there will be a continued need to synchronize the process to underscore a win-win result. The experiences of the past years have demonstrated how difficult that can be in securing domestic support as well as successful negotiations. Given the fact that the European Union negotiates its trade relations as a unit for all twenty-seven members, arriving at a common goal is a complicated process in Brussels as it is with their trade partners.

Underlying these and other central policies issues is the trust factor in transatlantic relations. The bonds between the elites on both sides of the Atlantic have experienced many roller coaster rides in the transatlantic relationship but they have held up against these challenges for the most part. That is a particularly unique dimension and resource to the Euro-American bond.

Yet what is now more problematic is the trust and confidence within the general public with regard to those elites and their assumptions about the transatlantic relationship. The picture of confidence in the United States according to recent surveys has shown a significant drop in many European countries which are largely attributable to the dislike of Trump. We have witnessed similar trends in earlier chapters such as the in the early Ronald Reagan administration and in that era of George W. Bush particularly after the Iraq war. The Obama era was associated with a far greater level of confidence in the transatlantic relationship due to the president's popularity. Yet mixed in these trends are uncertainties about the U.S. as Biden enters his presidency.

The Biden messages should be read by Europeans with the following caveats in mind. As a global power, the United States will be inevitably focusing on multiple centers of interest and concern, including Europe but increasingly on the Asian arena. Europeans should share both interest and concerns and demonstrate that responding to these shifts of power and influence can be best accomplished in close cooperation with Europe. In addition, confusion and contradictions emerging from the debate over its role on the global stage will be a reflection of a clash of interests and ambitions unique to the American political system. As Michael Kimmage (2020, p. 21) has advised.

Have patience. American politics was designed to be a chaotic collision of interests, and this is what it is. Jimmy Carter rejected Nixon's foreign policy as corrupt. Ronald Reagan rejected Carter's foreign policy as naïve. Bill Clinton rejected Reagan's foreign policy as old-fashioned. George W. Bush rejected Clinton's foreign policy - pre-9/11 - as hubristic. Obama rejected Bush's foreign policy as aggressively wrong. Trump rejected Obama's foreign pol- 
icy as progressive and therefore deluded. Biden will likely retain elements of Trump's conflict-ridden China policy. He is certain, though, to reverse the spirit of Trump's foreign policy, its emphasis on ethno-nationalist unilateralism, its indifference to democracy and human rights and its hostility to the European Union in general and to Germany in particular.

Kimmage (2020, p. 21) goes on to conclude:

Polarization and disagreement are the norm for the United States, as are bad foreign-policy decisions. But behind these colourful reversals, and behind the many wrong turns, is an approach to foreign policy that goes back to Thomas Jefferson's Declaration of Independence, in which the ideals of democracy and - since Woodrow Wilson - of multilateral deliberation are enshrined. Historically, the United States has deviated and returned to this approach, which is the common ground of the transatlantic relationship. Since 2016, it has deviated mightily. Amid the many present-day uncertainties, the United States is still likely to return to the fold.

That prognosis will greatly depend on the ability of Biden to sustain domestic stability, renewed growth and confidence in the future, most especially in the role of the United States on the world stage.

\section{The German-American partnership}

The key European relationship for the Biden administration will be with Germany. As the strongest economy and political heavyweight in the European Union, Biden will require leadership from Berlin in securing an effective transatlantic partnership. Germany's leadership will be in transition in 2021 after sixteen years of Angela Merkel's run as chancellor. The candidates aspiring to follow her will be campaigning in the first half of 2021. They will need to articulate how they see Germany's role and responsibilities in the coming years and how they envision a relationship with the United States.

A report of the Munich Security Conference released before the Nov 2020 elections focused on Germany's challenges at length. It argued:

The world is witnessing a Zeitenwende, the turn of an era and the beginning of a new, more dangerous one. For Germany, which had settled into the liberal international order like hardly any other country, it represents a particularly substantive challenge. Foreign policy "certainties" have become fragile. Although many in Germany are beginning to recognize the enormous challenges, Berlin is struggling to make the necessary adjustments. The watchword is Wendezeiten, we need to embrace change. Only by doing so can the European Union - and with it Germany - become capable of acting in an increasingly rough security environment. (MSC 2020, p. 219)

The Biden foreign policy team is made up of people who are familiar with Germany and Europe in general. The Secretary of State Antony Blinken spent years 
in Paris and accompanied Biden throughout his time as Vice President. The ability to find common ground between Biden's administration will be no doubt enhanced by these previous records of contacts. Biden's intention to rejoin the Paris Accord on Climate as well as the Joint Comprehensive Plan of Action effort are signals of cooperation, as is his proposal to have a summit of democracies.

The Biden presidency represents a chance to transform the U.S.-German partnership as a catalyst for transatlantic relations by thinking globally about the challenges ahead. The Trump era generated a serious decline among Germans who regard the United States favorably, according to a September 2020 Pew Research Center poll (Pew Research Center 2020). This was not only due to the president's style. His policies were also a source of anger. President Trump's threats to implement U.S. troop withdrawals from Germany were seen as retribution for Merkel's decision not to travel to Washington for a G7 meeting (Bennhold 2020). Threats of tariffs, sanctions and accusations of fealty toward Russia (somewhat hypocritical as seen by the Germans given Trump's close relationship with Putin) were also part of the alienation.

In contrast, President Biden has signaled his commitment to the many organizations and institutions in which Germany and the United States have shared interests from NATO to the World Health Organization, the United Nations or the European Union, the World Trade Organization to trade regimes. However, both the United States and Germany are in different situations than was the case when Biden was Vice President under Obama. A transition in leadership in Germany is pending and Biden's presidency after Trump will not have the same impact on German public opinion as did Obama after Bush Jr. The legacy of Trump leaves Germans wondering whether another Trump figure could emerge in four years and Biden's image as the oldest president in American history leaves many Germans thinking he may only serve one term. Merkel's departure will raise questions about the direction of Germany's foreign policy both in bilateral relations as well as in the larger framework of transatlantic affairs.

Yet Germany's pivotal role in Europe and its policy decisions in the world arena remains of consequence for the United States. That is particularly the case with an eye on the unpredictable fall out of Brexit and the future of the relationship between the UK and the European Union in question. Britain's ability to assist the United States in bridge-building within Europe was dramatically curbed by Brexit.

Relations between Berlin and Paris will also be critically important as well in dealing with a coherent European Union capacity to act as a partner.

There will be a number of particularly important issues for German-American relations. Given Germany's economic and political strength, there can be no effective Western policy toward Russia without close cooperation between Berlin and Washington. A coordinated approach will be a prerequisite for unity within the EU and NATO, in dealing with sanctions policies. In that connection, a Biden administration priority will include canceling the order to remove a large portion of U.S. troop presence in Germany. The strategic value of the American military presence in Germany is global in scope, apart from its deterrent value vis a vis Russian military threats. At the heart of this decision will be a reaffirmation of article five of the NATO treaty. 
The challenges with regard to Russia will also involve the Nord Stream 2 gas pipeline. This has caused a great deal of tension across the Atlantic as the U.S. Congress threatens to use sanctions against this project, arguing that Russian influence is enhanced by its completion. While the project is controversial within Europe and within Germany, the attempt to exercise U.S. influence on it has generated much German blowback even from those who are critical of the project. The solution to this clash will require a compromise involving a likely acceptance that the pipeline will be completed but with Germany diversifying its gas supply including increased supplies from the U.S., and certifying guarantees to protect that supply for the Ukraine.

On other issues such as dealing with a more aggressive China, Biden's administration will understand that without a unified West, China will divide and conquer. Here, too, Germany remains the key player in Europe given that it has the strongest economic relationship with China of any EU member state. The Biden administration will be well advised to take advantage of the increasing concerns in Berlin about China's challenges by proposing greater coordination in defending intellectual property right and forging the rules in trade and investment relations. Agreement on dealing with Huawei in creating $5 \mathrm{G}$ networks will be of central importance. As a gesture of cooperating, the Biden administration will likely cancel the tariffs on European steel and aluminum imports.

Understanding the COVID-19 pandemic as an international challenge, has opened opportunities to coordinate the responses. The fact that a team of German scientists at BioNTech and Americans at Pfizer were able to combine forces to create a vaccine is an illustration for cooperative opportunities to not only address the current pandemic but also prevent future ones.

The Biden administration has emphasized the cardinal importance of climate change in its agenda which opens potential for a broad discussion of energy and environmental security to mutual benefit. Prior to the Trump administration Obama had encouraged an expanded network of German cooperation at multiple levels. That network can be reignited under Biden who will demonstrate his commitment to the issue by rejoining the Paris Accord.

\section{Conclusion}

Whereas the Trump administration has systematically alienated Europeans, Biden and his people have already begun a transatlantic healing campaign. Rhetorically, at least, the contrast could not be starker. However, it remains unclear to what extent the Biden administration will simply embrace the European Union across the many issues on the transatlantic agenda. The discussions about trade and regulatory issues will continue to be shaped by the competing interests on both sides of the pond, be they in the industrial and technological sectors and questions regarding security of supply, privacy and data protection. Razor thin majorities held by the Democrats in the senate and in the house will sustain pressures for protectionist measures in dealing with tough trade negotiations. 
On defense, Biden's embrace of NATO can enhance cooperation in areas like technological innovation. However, if there are arguments within the EU about European sovereignty or autonomy in areas of transatlantic concern, finding common ground might be more challenging with Washington.

The emphasis Biden brings to the issue of human rights and the need to confront autocracies will underscore his commitment to a multilateral agenda. That will require working out the details of dealing with competitive powers particularly China both on the transatlantic stage as well as in the domestic frameworks.

Joe Biden ended his Foreign Affairs article with this claim primarily aimed at an American audience.

We must once more harness that power and rally the free world to meet the challenges facing the world today. It falls to the United States to lead the way. No other nation has that capacity. No other nation is built on that idea. We have to champion liberty and democracy, reclaim our credibility, and look with unrelenting optimism and determination toward our future. (Biden 2020)

Gaining support for this agenda at home will be the new President's first major challenge. Recruiting support for it on the world stage will run a close second.

\section{References}

Bennhold, K. (2020, 6 June). Has 'America First' become 'Trump First'? Germans wonder. The New York Times. https://www.nytimes.com/2020/06/06/world/europe/germany-troop-withdrawal-america. html. Accessed 18 Jan. 2020.

Biden, J.R. (2020). Why America must lead again. Rescuing U.S. foreign policy after Trump. Foreign Affairs. https://www.foreignaffairs.com/articles/united-states/2020-01-23/why-america-must-leadagain. Accessed 5 Jan. 2021.

DGAP - Deutsche Gesellschaft für Auswärtige Politik (2020). Stronger together. A strategy to revitalize transatlantic power. https://dgap.org/sites/default/files/article_pdfs/StrongerTogether.pdf. Accessed 18 Jan. 2020.

European Commission (2020). Joint Communication to the European Parliament, the European Council and the Council. https:/eur-lex.europa.eu/legal-content/EN/TXT/HTML/?uri=CELEX:52020JC0022 \&rid=7. Accessed 18 Jan. 2021.

GMF - German Marshall Fund (2020). Together or alone? Choices and strategies for transatlantic relations for 2021 and beyond. https://www.gmfus.org/publications/together-or-alone-choices-and-strategiestransatlantic-relations-2021-and-beyond. Accessed 18 Jan. 2021.

Gottemoeller, R. (2019, 19 Dec.). NATO is not brain dead. Foreign Affairs. https://www.foreignaffairs. com/articles/united-states/2019-12-19/nato-not-brain-dead. Accessed 11 Jan. 2021.

Kimmage, M. (2020). Transatlantic ups and downs. What our past can teach us about our future. The Berlin Pulse. German foreign policy in perspective 2020/21, 20-21.

Kupchan, C. A. (2012). No one's world. Oxford: Oxford University Press.

MSC - Munich Security Conference (2020). Zeitenwende Wendezeiten. Special Edition of the Munich Security Report on German Foreign and Security Policy. https://securityconference.org/assets/01_ Bilder_Inhalte/03_Medien/02_Publikationen/MSC_Germany_Report_10-2020_Engl.pdf. Accessed 18 Jan. 2021.

NATO (2020). NATO 2030: United for a new era. https://www.nato.int/nato_static_fl2014/assets/pdf/2020/ 12/pdf/201201-Reflection-Group-Final-Report-Uni.pdf. Accessed 18 Jan. 2021.

Pew Research Center (2020). U.S. image plummets internationally as most say country has handled coronavirus badly. In Germany, roughly a quarter regard U.S. positively. https://www.pewresearch.org/ global/2020/09/15/us-image-plummets-internationally-as-most-say-country-has-handled-coronavir us-badly/pg_2020-09-15_u-s-image_0-09/. Accessed 18 Jan. 2021. 
Saldinger, A. (2020, 19 Oct.). African leaders question US position on China at investment event. Devex news. https://www.devex.com/news/african-leaders-question-us-position-on-china-at-investmentevent-98347. Accessed 5 Jan. 2021.

Tocqueville, A. (1835). Democracy in America. London: Saunders and Otley. 